\title{
Factors associated with demand for epidural analgesia among women in labor at a tertiary hospital in Nnewi, South-East, Nigeria
}

\author{
Samuel C Ojiakor 1, 2, Afam B Obidike 2, Kenneth N Okeke 2, Chioma P Nnamani 3, 4, Amaka L Obi-Nwosu 3,4, \\ Richard O Egeonu 5, George U Eleje 5, 6, ${ }^{*}$ and Chukwuemeka J Ofojebe 5, 6 \\ ${ }^{1}$ Department of Anesthesiology, Nnamdi Azikiwe University, Awka, Anambra State, Nigeria. \\ ${ }^{2}$ Department of Anesthesiology, Nnamdi Azikiwe University Teaching Hospital (NAUTH), Nnewi, Anambra State, Nigeria. \\ ${ }^{3}$ Department of Family Medicine, Nnamdi Azikiwe University, Awka, Anambra State Nigeria. \\ ${ }^{4}$ Department of Family Medicine, Nnamdi Azikiwe University Teaching Hospital, (NAUTH), Nnewi, Anambra State, \\ Nigeria. \\ ${ }^{5}$ Department of Obstetrics \& Gynecology, Nnamdi Azikiwe University Teaching Hospital, (NAUTH), Nnewi, Anambra State, \\ Nigeria. \\ ${ }^{6}$ Department of Obstetrics \& Gynecology, Nnamdi Azikiwe University, Awka, Anambra State, Nigeria.
}

Magna Scientia Advanced Research and Reviews, 2021, 02(01), 008-013

Publication history: Received on 10 February 2021; revised on 15 March 2021; accepted on 18 March 2021

Article DOI: https://doi.org/10.30574/msarr.2021.2.1.0028

\begin{abstract}
Background: Epidural labor analgesia has become prevalent in high income countries, but its use in low and middle income countries such as Nigeria is poorly studied.

Objectives: To determine the rate of demand, indications, post-dural puncture headache rate and factors affecting demand for epidural analgesia among women in labor.

Method: This was a across sectional analytical study of women in labor who were managed at Nnamdi Azikiwe University Teaching Hospital Nnewi, Nigeria from 1st January 2017 to 31st December 2017. Data was obtained from women's case files from Medical record department, labor ward, and Anesthesiology departmental records. Information obtained included total number of deliveries, mode of delivery, those that received epidural: date and time of placement, indication and number of side effects. Univariate analysis models were applied to evaluate the association between patient demographic, socioeconomic factors, clinical and demand for labor epidural analgesia. A p-value of $<0.05$ was taken as significant.
\end{abstract}

Results: Thirty-six women out of 1,373 women received epidural labor analgesia, giving the epidural labor analgesic rate of $2.6 \%$. The most common indication for epidural labor analgesia was maternal voluntary request which accounted for $24(66.7 \%)$ of the population receiving analgesia. One $(2.8 \%)$ parturient developed post-dural puncture headache which resolved spontaneously within 24 hours. Parturient who utilized labor epidurals were significantly older than 30 years of age (OR 3.16; 95\% CI 1.51-6.62; p=0.002), Multi-parous (OR 26.65; 95\% CI 3.64-100.00; p=0.001), and with higher income (OR 9.02; 95\% CI 4.38-18.57; $\mathrm{p}=<0.001$ ), but not with higher level of education (OR 0.56; 95\% CI 0.27$1.16 ; \mathrm{p}=0.114)$.

Conclusion: The demand for labor epidural in the study center was low with a demand rate of $2.6 \%$ and post-dural puncture headache rate of $2.8 \%$. The significant factors related to a parturient's request for epidural analgesia during

\footnotetext{
${ }^{*}$ Corresponding author: Dr. George Uchenna Eleje

Department of Obstetrics and Gynaecology, Nnamdi Azikiwe University, Awka (Nnewi Campus), P.M.B. 5001 Nnewi, Anambra State, Nigeria.

Copyright $(2021$ Author(s) retain the copyright of this article. This article is published under the terms of the Creative Commons Attribution Liscense 4.0.
} 
labor included age greater than 30 years, multiparity and higher income. There is a need for an enhanced awareness programs on obstetrics epidural analgesia.

Keywords: Demand; Epidural analgesia; Labor; Post-dural puncture headache; Pregnant women

\section{Introduction}

Maternal childbirth care is one of the main indices of development of any nation and this could be gauged best by the type of labor analgesia she receives during pregnancy and childbirth [1-3]. Child birth unarguably is a desirable event but has been described as the most painful, emotionally and physically distressing experience affecting the mother, fetal wellbeing as well as progress of labor $[2,3]$. The increase sympathetic response to pain results is a marked elevation in the circulating levels of catecholamine leading to increase in the maternal cardiac output, systemic vascular resistance and oxygen consumption [3]. Parturient with pre-existing cardio-respiratory insufficiency, such increase may be dangerous. Besides these hemodynamic and metabolic changes, severe labor pain has been associated with postpartum posttraumatic stress disorder, depression and persistent pain [4]. Based on these, pain relief was therefore declared a fundamental human right and has been found to improve labor outcome and increased maternal satisfaction [5]. Various methods including non - pharmacological and pharmacological method have been deployed with varying degree of analgesic benefit [5]. Central neuraxial block (epidural analgesia) is the most versatile and effective method of labor analgesia. It involves the injection of Local anesthetics into the epidural space which consequently block the pain stimuli generated from nerve fibres of contracting uterus and dilating cervix[5-8]. Its use has been steadily increasing reaching approximately to $69 \%$ in US, Canada, Europe, Australia and Asia but not so in the low and middle income countries like Nigeria [5, 6, 9]. Against this backdrop, this study was conducted to determine the demand for epidural analgesia, indications, post-dural headache rate and factors affecting demand for epidural analgesia among women in labor who presented at the Nnamdi Azikiwe University Teaching Hospital, Nnewi, South east, Nigeria.

\section{Methods}

This was a cross sectional analytical study of women in labor who were managed at NAUTH labor ward from January 2017 to December 2017. The study protocol was approved by the Ethics Committee of Nnamdi Azikiwe University Teaching Hospital, Nnewi, Nigeria. Data was obtained from patients' case files from Medical record department, labor ward, and Anesthesiology departmental records. Information obtained included total number of deliveries, mode of delivery, those that received epidural: date and time of placement, indication and incidence of side effects. Standard epidural analgesia procedure including written informed consent, pulse oximetry and other vital signs monitoring was carried out in all the patients that requested for labor epidural analgesia. Under aseptic condition with the patient in sitting position, the epidural space was located at the L4/L5 inter-vertebra space using size 18G egementuohy needle through loss of resistance to air method. Thereafter, a multi-orifice epidural catheter was inserted into the epidural space. The tuohy needle subsequently removed and the catheter secured properly to the skin. Analgesia was constantly assessed and maintained with intermittent administration as top ups of dilute plain bupivacaine. The anesthesia monitoring and management continued into the postpartum period until the epidural catheter was removed. Data were collected using data collection sheet pre-designed for this study and were entered and analyzed using SPSS version 22. The results were presented in frequencies and percentages. Univariate analysis models were applied to evaluate the association between patient demographic, socioeconomic factors and clinical and demand for labor epidural analgesia. A p-value of $<0.05$ was taken as significant.

\section{Results}

A total of 1373 deliveries were recorded in NAUTH within the period under review. Spontaneous vertex delivery (SVD) and caesarean section accounted for 844 (61.5\%) and 529 (38.5\%) respectively while 36 women accounting for $2.62 \%$ received epidural labour analgesia. The mean age of the parturients that received epidural was ranged from 21-50 years. However, there was preponderance of patients with age range from 31- 40 years.(Table1)

The most common indication was maternal voluntary request for epidural labour analgesia which accounted for 24 $(66.7 \%)$ of the population. Other indications included pre-eclampsia $6(16.7 \%)$, cardiac diseases $3(8.3 \%), 2(5.6 \%)$ patients have sickle cell diseases while only one patient was a primigravida. (Table 2)

Majority of the patients who voluntarily requested for epidural were women of high educational status which cumulatively accounted for $25(69.4 \%)$ patients while the rest of the patients represent non-graduate and traders who accounted for $11(30.6 \%)$ patients who were counseled to receiving epidural based on their co-morbidity. (Table 3) 
There was a low incidence of complications recorded in this study, one patient who had her epidural analgesia upgraded to epidural anaesthesia for Caesarean section due to obstructed labour in a twin gestation also developed post-dural puncture headache but it resolved spontaneously within 24 hours.

Table 4 shows the association between demand for labor epidural analgesia and participants' socio-demographic variables based on univariate test. Parturients who utilized labor epidurals were significantly older than 30 years of age (OR 3.16, 95\% CI 1.51-6.62; p=0.002), multiparous (OR 26.65 95\% CI 3.64-100.00; p=0.001), and with higher income (OR 9.02, 95\% CI 4.38-18.57; $\mathrm{p}=<0.001$ ).

Table 1 Age distribution of study participants

\begin{tabular}{|l|l|l|}
\hline Age range (years) & Frequency $\mathbf{N}=\mathbf{3 6}$ & Percentage \\
\hline $21-30$ & 10 & 27.8 \\
\hline $31-40$ & 18 & 50.0 \\
\hline $41-50$ & 8 & 22.2 \\
\hline
\end{tabular}

Table 2 Indications for epidural analgesia

\begin{tabular}{|l|l|l|}
\hline Indications & Frequency N=36 & Percentage \\
\hline Voluntary & 24 & 66.7 \\
\hline Sickle cell disease & 2 & 5.6 \\
\hline Pre-eclampsia & 6 & 16.7 \\
\hline Cardiac disease & 3 & 8.3 \\
\hline Primigravida & 1 & 2.8 \\
\hline
\end{tabular}

Table 3Profession of study participants

\begin{tabular}{|l|l|l|}
\hline Profession & Frequency N= 36 & Percentage \\
\hline Medical Practitioner & 6 & 16.7 \\
\hline Legal Practitioner & 3 & 8.3 \\
\hline Banking & 7 & 19.4 \\
\hline Teaching & 4 & 11.1 \\
\hline Other graduates & 5 & 13.9 \\
\hline Non-graduates (Traders/Artisans) & 11 & 30.6 \\
\hline
\end{tabular}

Table 4 Association between demand for labor epidural analgesia and participants' socio demographic variables based on univariate test

\begin{tabular}{|l|l|l|l|l|}
\hline Variable & $\begin{array}{l}\text { Received epidural } \\
(\%)\end{array}$ & Did not receive epidural (\%) & OR (95\% CI) & P-value \\
\hline & $(\mathrm{N}=36)^{\mathrm{a}}$ & $(\mathrm{N}=1337)^{\mathrm{a}}$ & & \\
\hline Age > 30 years & $26(72.2)$ & $603(45.1)$ & $3.16(1.51-6.62)$ & 0.002 \\
\hline Multiparity & $35(97.2)$ & $759(56.8)$ & $26.65(3.64-100.00)$ & 0.001 \\
\hline High income earner & $25(69.4)$ & $269(20.1)$ & $9.02(4.38-18.57)$ & 0.001 \\
\hline $\begin{array}{l}\text { Higher level of } \\
\text { Education }\end{array}$ & $25(69.4)$ & $1072(80.2)$ & $0.56(0.27-1.16)$ & 0.114 \\
\hline
\end{tabular}

Abbreviations: OR=0dds ratio; 95CI=95\% Confidence Interval; a=Values are given as number (percentage). 


\section{Discussion}

The findings from this study showed that the demand for labor epidural analgesia was very low (2.6\%) which was comparable with the results from other African settings. This agrees with previous South African independent reports of level of labor epidural utilization of $1.6 \%$ and $2.2 \%$ respectively $[10,11]$. It is also lower than $7.5 \%$ reported by Ezeonu in Abakiliki Nigeria and 10.6\% reported by Olaleye et al in Ilesha, Nigeria [5]. However, in high income countries, the findings were completely at variance with reported high level of labor epidural utilization ranging from $29 \%$ to over $69 \%[9,12]$.

Childbirth appears to be the most painful experience encountered by most pregnant women and the experience of the pain could be very unique to the individual women, so it is only the woman in labor that can describe the extent of the pain she is experiencing [3]. The most predominant indication for labor epidural analgesia in this study was maternal voluntary request accounting for $66.7 \%$ of parturients who utilized epidural analgesia. This finding was similar to the report of other studies that documented patient's request as the most common reason for instituting labor epidural analgesia [5,6]. This is in keeping with the recommendations of the American Society of Anesthesiologists (ASA) and American College of Obstetrician and Gynecologists (ACOG) on labor analgesia [7, 8]. These two bodies recommended that; maternal request is a sufficient justification for pain relief during labor and that no woman should be allowed to experience untreated pain amenable to safe intervention while under the care of a physician in the absence of any contraindication [7,8].The other patients in our study who received epidural were counseled based on the conditions complicating their pregnancy including pre-eclampsia, sickle cell disorders and cardiac diseases.

Our study further noted that educated women dominated the demand for epidural analgesia because they are better informed about the trending events especially as it concerns their reproductive health. This submission therefore suggests that their knowledge of epidural technique for labor pains could have contributed to the level of demand observed which corroborated the reports of other authors [10-13].Additionally, parturients who utilized labour epidurals were significantly older than 30 years of age $(p=0.002)$, multiparous $(p=0.001)$, and were higher income earners $(\mathrm{p}=<0.001)$ This was in consistent with previous Vietnam Study [1]. .Apart from the knowledge of labor epidural analgesia, a few other concerns had continued to challenge its wide use in our setting which included the effect of epidural analgesia on the outcome of labor in terms of progress of labor, mode of delivery and backache. In as much as some studies have reported an association between epidural placement and prolongation of the duration of first and second stages of labor, instrumental vaginal and cesarean delivery [14,15].

Our study and that of many other recent studies did not support these reports [17-21]. This index study reported only one case whose epidural analgesia was upgraded to epidural anesthesia by increasing the concentration of the local anesthetic for cesarean section due to obstructed labor in a twin gestation.

Sharma and associates reported identical rates of cesarean section among women who received either lumbar epidural analgesia or intravenous meperidine analgesia [17]. Lyon and colleagues also evaluated the impact of intrapartumanalgesia on obstetric outcome at a United States Air Force hospital over a 12-months period [18]. They noted a reduction in the incidence of cesarean delivery among parturients that utilizes lumbar epidural analgesia compared to women with other forms of analgesia. Another study conducted by Fyneface-Ogan and coworkers also noted that the incidence of operative delivery and duration of first and second stages of labor were rather significantly reduced and shorter respectively among women who received epidural analgesia compared to the non- epidural group [19]. A meta-analysis comprising of 18 studies involving 6,600 women compared incidence of cesarean section and the duration of the stages of labor among the groups that received epidural analgesia and those that did not. The incidences of cesarean section were similar in the groups and there was no difference in the length of the first and second stages of labor [20].

Accidental dural puncture is a recognized complication of labor epidural placement and can cause a debilitating headache [2]. Interestingly, there was low incidence of complication noted in this study. We observed one case (2.8\%) post-dural puncture headache but resolved spontaneously within 24 hours without any residual symptoms. This finding was similar to those reported from South Africa [10] and in high income countries [11,12]. This suggests that epidural analgesia can effectively and safely be deployed for women in labor [21-24]. Accidental dural puncture complication rates have been noted to decrease once the anesthetist is trained and experienced.

The limitations in this study included the small number of cases enrolled and the retrospective design which was based on the fact that there was no dedicated labor analgesia service in our institution and largely based on maternal request. The strength of the study was that the study appears to be the first study in the study center to comprehensively describe the demand for obstetrics epidural analgesia. 


\section{Conclusion}

The demand for labor epidural in the study center was low with a demand rate of $2.6 \%$ and post-dural puncture headache rate of $2.8 \%$. The significant factors related to a parturients' request for epidural analgesia during labor included age greater than 30 years, multiparity, and higher income. The low incidence of complications shown in this study suggests that labor epidural analgesia can be safely and effectively deployed. Our study also further revealed that parturient with high educational status predominantly demanded for epidural analgesia. There is a need for an enhanced awareness programs on obstetrics epidural analgesia. We also recommend a dedicated labor epidural analgesic service in the teaching hospital with a multi-disciplinary framework comprising of Anesthesiologists, Obstetricians, Family Physicians and Midwives.

\section{Compliance with ethical standards}

\section{Acknowledgments}

The authors appreciate the hospital management for the permission granted to carry out this study.

\section{Disclosure of conflict of interest}

All authors declare that they have no conflict of interest.

\section{Statement of informed consent}

The study is a retrospective study, the information was extracted from the patients' medical records. However, informed consent was obtained from the patients before they received epidural analgesia.

\section{Authors' contribution}

Samuel C Ojiakor, Afam B Obidike, and Kenneth N Okeke were involved in the overall conceptual design and implementation of the project, and overall revision of the manuscript. Chioma P Nnamani, Amaka L Obi-Nwosu, and Richard $\mathrm{O}$ Egeonu were involved in the writing of this manuscript and overall revision. George U Eleje, and Jude C Ofojebe were involved in revision of the manuscript. All authors have made substantial contributions to: conception and design of the study, or acquisition of data, or analysis and interpretation of data; drafting the article or revising it critically for important intellectual content; and final approval of the version submitted.This manuscript has not been submitted for publication in another journal.

\section{References}

[1] Nguyen LD, Nguyen AD, Farber MK, Phan CT, Khuat LT, Nguyen HT, Dang TM, Doan HTN. Sociodemographic Factors Associated with Request for Labor Epidural Analgesia in a Tertiary Obstetric Hospital in Vietnam. Biomed Res Int. 30 Jan 2021; 8843390.

[2] Sidhu NS, Cavadino A, Ku H, Kerckhoffs P, Lowe M. The association between labour epidural case volume and the rate of accidental dural puncture. Anaesthesia. 25 Jan 2021.

[3] Oyediran OO, Faronbi JO, Ayandiran OE, Olatubi MI, Akinyoola OD. Factors associated with intention to use epidural analgesia during labour among pregnant women attending antenatal clinic of a tertiary health institution in Southwestern Nigeria, Int. J. Nurs. Midwifery. 2020; 12(4):139-150.

[4] Bonapace J, Gagné GP, Chaillet N, Gagnon R, Hébert E, Buckley S. No. 355-Physiologic Basis of Pain in Labour and Delivery: An Evidence-Based Approach to its Management. J ObstetGynaecol Can.Feb 2018;40(2): 227-245.

[5] Olaleye O, Dada SO, Alabi GO. Awareness and Utilization of Obstetric Epidural Analgesia in LabourAmongPregnant Women in Wesley Guild Hospital Ilesha, Nigeria. Int Q Community Health Educ. 3 Dec 2020; 272684X20972839.

[6] Ezeonu PO, Anozie OB, Onu FA, Esike CU, Mamah JE, Lawani LO, Onoh RC, Ndukwe EO, Ewah RL, Anozie RO. Perceptions and practice of epidural analgesia among women attending antenatal clinic in FETHA. Int J Womens Health. 12 Dec 2017;9:905-911. 
[7] Practice guidelines for Obstetric Anesthesia: An updated reportby American Society of Anesthesiologists Task force on Obstetric Anesthesia and the Society for Obstetric Anesthesia and Perinatology. Anesthesiology. 2016; 124(2):270-300.

[8] ACOG Pain relief during labour. Committee Opinion. 2004 (4); 295: 1.

[9] Ali Alahmari SS, ALmetrek M, Alzillaee AY, Hassan WJ, Ali Alamry SM. Knowledge, attitude, and practice of childbearing women toward epidural anesthesia during normal vaginal delivery in Alsanayeah Primary Health Care in KhamisMushait. J Family Med Prim Care. 28 Jan 2020;9(1):99-104.

[10] Leonard T, Perrie H, Seribante J, Chetty S: An audit of labour epidural analgesia service at a regional hospital in GautingProvince, South Africa. SAJOG. 2018;24(2): 52-56.

[11] Jacobs MG, Burkie L, Lewis A, Coetzee A. Labour epidural analgesia in a state tertiary hospital in South Africa. South Afr J Anaesth\&Analg.2014;20(4):174-78.

[12] Raynes-Green now CH, Roberts CL, McCaffery K, Clarke J. Knowledge and decision making for labour analgesia of Australian primiparous women. Midwifery. 2007; 23: 139-145.

[13] Okojie NO, Isah EC. Perception of epidural analgesia for labour among pregnant women in a Nigerian teaching hospital setting. J West AfrColl Surg.2014;4(4):142-62.

[14] Wong CA. Advances in labour analgesia. Int J Women Health.2009; 1: 139-154.

[15] Vincent DR, Chestnut DH. Epidural analgesia during labour. Am Fm Physician. Labour. 1998; 58 (8): 1785 - 1792.

[16] Wesan FM, Roshdi AL-M, Manal M. Epidural analgesia during labour Vs no analgesia: A comparative study: Saudi J Anaesth. 2012; 6(1): 36-40.

[17] Sharma SK, Sidani JE, Ramin SM, Lucas MJ, Laveno KJ, Cunningham FG. Caesarean delivery in a randomized trial of epidural versus patient controlled intravenous meperidine analgesia during labour. Anesthesiology. 1997;87: 487-94.

[18] Lyon DS, Knuckles G, Whitaker E, Salgado S. The effect of instituting and elective epidural program on the operative delivery rate. Obstetr Gynecol.1997; 90: 135- 41.

[19] Fyneface-Ogan S, Mato CN, Anya SE. Epidural anesthesia: Views and outcome of women in labor in a Nigerian hospital. Annals of African Medicine. 2009; 8(4): 250-56.

[20] Howell CJ, Dean T, Lucky L, Dziedzik K, Jones PW, Johnson RB. Randomized study of long-term outcome after epidural versus non- epidural analgesia during labour. BMJ. 2002; (14): 325 -357.

[21] Lim Y, Sia AT. Dispelling the myths of epidural pain Relief in childbirth. Singapore Med J. 2006;47: 1096.

[22] Anozie OB, Lawani LO, Mamah JE, Esike CO, Ezeonu OP, Eze JN, et al. Epidural analgesia for management of labour pains: Deterrents Among Obstetrician in Nigeria. International Journal of Women's Health and Reproductive Sciences. 2018; 6(4): $410-14$.

[23] Bitew A, Workie A, Seyum T, Demeke T. Utilization of obstetric analgesia in labourpain management and associated factors among obstetric care givers in Amhara Regional state referral Hospitals, Northwest Ethiopia. A Hospital based cross sectional study. J Biomedical Sci. 2016; 5(2):1-6.

[24] Madden KL, Turnbull D, Cyna AM, Adelson P, Wilkinson C. Pain relief for childbirth: the preferences of pregnant women, midwives and obstetricians. Women Birth. 2013; 26: 33-40. 